\title{
A Comparative Study of Stabilities and Coordination Modes of $\beta$-Alaninephosphonic Acid in Copper(II) Heteroligand Complexes with Ethylenediamine, Diethylenetriamine or $N, N, N^{\prime}, N^{\prime}, N^{\prime \prime}$-Pentamethyldiethylene Triamine in Aqueous Solution
}

\author{
Anna Kamecka
}

Received: 10 October 2011/Accepted: 18 January 2012/Published online: 8 November 2012

(C) The Author(s) 2012. This article is published with open access at Springerlink.com

\begin{abstract}
Solution equilibrium studies on $\mathrm{Cu}^{2+}-\mathrm{L}_{1}-\mathrm{L}_{2}$ ternary systems have been performed by $\mathrm{pH}$-potentiometry, $\mathrm{UV}-\mathrm{V}$ is spectrophotometry and EPR methods \{where $\mathrm{L}_{1}$ corresponds to a polyamine such as ethylenediamine (en), diethylenetriamine (dien), $N, N, N^{\prime}, N^{\prime}, N^{\prime \prime}$-pentamethyldiethylenetriamine ( $\left.\left.\mathrm{Me}_{5} \operatorname{dien}\right)\right\}$ and $\mathrm{L}_{2}$ denotes 2-aminoethylphosphonic acid ( $\beta$-alaninephosphonic acid) $\}$. The results suggest the formation of heteroligand complexes with $\left[\mathrm{Cu}\left(\mathrm{L}_{1}\right)(\beta-\mathrm{Ala}(\mathrm{P}))\right]$ stoichiometry in all of the studied systems. Additionally, in the system with en, $\left[\mathrm{Cu}(\mathrm{en})(\beta-\mathrm{Ala}(\mathrm{P})) \mathrm{H}_{-1}\right]^{-}$is formed in basic solutions. Our spectroscopic results indicate tetragonal geometry for the $[\mathrm{Cu}(\mathrm{en})(\beta-\mathrm{Ala}(\mathrm{P}))]$ species, a geometry slightly deviated from square pyramidal for the $[\mathrm{Cu}(\operatorname{dien})(\beta-\mathrm{Ala}(\mathrm{P}))]$ complex, and somewhat stronger geometry distortion was present for the $\left[\mathrm{Cu}\left(\mathrm{Me}_{5} \mathrm{dien}\right)(\beta-\mathrm{Ala}(\mathrm{P}))\right]$ complex. The coordination modes in these heteroligand complexes are discussed.
\end{abstract}

Keywords Copper(II) complexes - Heteroligand complexes - Aminophosphonic acids · EPR · Vis spectroscopy · Potentiometry · Equilibria $\cdot$ Stability constants · Polyamines

\section{Introduction}

Aminoalkylphosphonic acids occupy an important place among the various compounds containing a $\mathrm{P}-\mathrm{C}$ bond and the amino group because they are analogues of natural amino acids, the 'building blocks' of peptides and proteins. Their utilities as enzyme inhibitors, anticancer agents, antibiotics, neuromodulators, plant growth regulators and herbicides, antibacterial compounds, and many other technical and industrial applications such as chelating agents and scale inhibitors have attracted the interests of chemists for a long time $[1,2]$. So, it is worthwhile to assemble information on their formation, stability and structure, and the mutual influence of two different ligands bound to the same metal ion.

\footnotetext{
A. Kamecka $(\bowtie)$

Institute of Chemistry, Siedlce University of Natural Sciences and Humanities,

3-Maja 54, 08-110 Siedlce, Poland

e-mail: akamecka@uph.edu.pl
} 
Chemical speciation calculations based on numerical equilibrium data are of extreme importance for potential future developments.

Our research work on heteroligand complexes with some polyamines and aminophosphonic acids such as glycinephosphonic acid $(\mathrm{Gly}(\mathrm{P}))$ and $\alpha$-alaninephosphonic acid $(\alpha-\mathrm{Ala}(\mathrm{P}))$, which are analogues of amino acids, have shown that the substitution of the carboxylate group by the phosphonic function distinctly changes the coordination ability of the ligand in ternary systems [3,4]. The studies have also demonstrated that, in the heteroligand complexes, the geometry around copper(II) is closely related to the type of polyamine, i.e., to the number of nitrogen atoms of the polyamines which are potential coordination sites. As a continuation of the previous studies, the $\beta$-derivative of aminophosphonic acid in the ternary systems has been investigated. According to our knowledge, no data exist for the ternary systems with $\beta$-aminophosphonic acids. The arrangement of the donor atoms in $\beta$-derivatives of aminophosphonic acid allows for the formation of a six-membered chelate ring. Thus, it seems to be interesting to investigate whether such structural arrangement of the ligand affects the coordination geometry of the heteroligand complexes to the same extent as was observed in the ternary systems with an $\alpha$-derivative of aminophosphonic acid [3, 4], amino acids [5, 6] or aminohydroxamic acids [7-11].

Consequently, the present paper reports studies on the systems $\mathrm{Cu}^{2+}-\mathrm{L}_{1} \mathrm{~L}_{2}$ \{when $\mathrm{L}_{1}=$ ethylenediamine (en), diethylenetriamine (dien) or $N, N, N^{\prime}, N^{\prime}, N^{\prime \prime}$-pentamethyldiethylene triamine $\left(\mathrm{Me}_{5} \mathrm{dien}\right)$, and $\mathrm{L}_{2}=2$-aminoethylphosphonic acid ( $\beta$-alaninephosphonic acid) $(\beta-\mathrm{Ala}(\mathrm{P})\}$ using $\mathrm{pH}$-metric, spectrophotometric, and EPR methods.

Systematic comparisons between different $\mathrm{Cu}^{2+}-\mathrm{L}_{1} \mathrm{~L}_{2}$ ternary system with $\mathrm{L}_{2}=\mathrm{Gly}(\mathrm{P})$ or $\alpha$-Ala $(\mathrm{P})$ have been performed. Although these systems exhibit many similarities, some important differences are also found. The differences between the complex-forming properties of aminophosphonates and aminocarboxylates in ternary systems have been explained by differences in basicity, charge and size of the $-\mathrm{PO}_{3}^{2-}$ and $-\mathrm{COO}^{-}$groups.

\section{Experimental}

\subsection{Chemicals}

Ethylenediamine dihydrochloride (en-2HCl), diethylenetriamine, $N, N, N^{\prime}, N^{\prime}, N^{\prime \prime}$-pentamethyldiethylene triamine, and 2-aminoethylphosphonic acid were purchased from SigmaAldrich Chemical Co. All chemicals were of purity greater than $99 \%$ and they were used without further purification. The purity of the ligands and the concentrations of the ligand stock solutions used for potentiometric measurements were determined by Gran's method [12]. The $\mathrm{CuCl}_{2}$ and $\mathrm{HCl}$ standard stock solutions were prepared from Titrisol concentrates (Merck). The exact concentration of copper ions in the stock solution was determined via complexometric ethylenediaminetetraacetate titration. The $\mathrm{HCl}$ concentration was determined by $\mathrm{pH}$-potentiometric titrations using Gran's method [12]. Carbonate-free potassium hydroxide solution (the titrant) was prepared from $\mathrm{cc}$. $\mathrm{KOH}$ and standardized against a standard potassium hydrogen phthalate solution. All solutions were prepared with bidistilled water. The formulae of the fully protonated form of the ligands used in this study are shown in Scheme 1. 
<smiles>[NH3+]CC[Pb]([O-])([O-])[OH2+]</smiles>

$\beta$-alaninephosphonic acid<smiles>[NH3+]CC[NH3+]</smiles>

Ethylenediamine<smiles>[NH3+]CC[NH2+]CC[NH3+]</smiles>

$\left[\mathrm{H}_{3} \text {-dien }\right]^{3+}$

Diethyleneotriamine<smiles>C[NH+](C)CC[NH+](C)CC[NH+](C)C</smiles>

\section{$\left[\mathrm{H}_{3}-\mathrm{Me}_{5} \mathrm{dien}\right]^{3+}$}

$\mathrm{N}, \mathrm{N}, \mathrm{N}$ ',N',N' '-pentamethyldiethylenetriamine

Scheme 1 Formulae of the fully protonated forms of the ligands

\subsection{Potentiometric and Spectroscopic Studies}

The pH-potentiometric measurements were carried out at an ionic strength of $0.2 \mathrm{~mol} \cdot \mathrm{dm}^{-3}(\mathrm{KCl})$ at the temperature $25.00 \pm 0.1{ }^{\circ} \mathrm{C}$. Carbonate-free $\mathrm{KOH}$ solution of known concentration (ca., 0.15 or $0.3 \mathrm{~mol} \cdot \mathrm{dm}^{-3}$ ) was used as titrant. A MOLSPIN automatic titrator system equipped with a combination $\mathrm{pH}$ electrode (Single Pore Plast or Single Pore Glass, Hamilton) was used for $\mathrm{pH}$-potentiometric measurements. The electrode system was calibrated by periodic titrations of an $\mathrm{HCl}$ solution $\left(0.008 \mathrm{~mol} \cdot \mathrm{dm}^{-3}\right.$ in $\left.\mathrm{KCl}\right)$ against standard $\mathrm{KOH}$ solution. The resulting titration data were used to calculate the standard electrode potentials, $E^{\circ}$, and the dissociation constant for water $\left(\mathrm{p} K_{\mathrm{w}}=13.74 \pm 0.02\right)$. These values were then used to calculate the hydrogen ion 
concentration $\left[\mathrm{H}^{+}\right]$from the emf readings [13]. All of the $\mathrm{pH}$-potentiometric titrations were performed under an argon atmosphere over the $\mathrm{pH}$ range of 2-11 or until precipitation occurred. The initial volume of the samples was $5.00-6.00 \mathrm{~cm}^{3}$. For the binary systems the ligand concentration was $(2.5-3) \times 10^{-3} \mathrm{~mol} \cdot \mathrm{dm}^{-3}$ and the copper(II) ion concentrations varied over the range of $(0.6-3) \times 10^{-3} \mathrm{~mol} \cdot \mathrm{dm}^{-3}$ according to the metal ion-to-ligand ratios: 1:1, 1:2 and 1:4. For the ternary systems the ratios of copper(II):en/ dien/Me ${ }_{5} \operatorname{dien}: \beta-A l a(P)$ were $1: 1: 1,1: 1: 2,1: 2: 1,1: 2: 2$ and $0.5: 1: 1$. Titrations were usually made on samples containing copper(II) ion concentrations of $(2.5-3) \times 10^{-3} \mathrm{~mol} \cdot \mathrm{dm}^{-3}$ or $1.25 \times 10^{-3} \mathrm{~mol} \cdot \mathrm{dm}^{-3}$ (in the case of the $0.5: 1: 1 \mathrm{molar}$ ratio). The $\mathrm{pH}$-metric results were utilized in order to find the stoichiometry of the species and to calculate the stability constants of the species formed in the ternary systems. The calculations were made with the aid of the computer program HYPERQUAD 2006 [8]. The equilibrium models for the ternary systems and the corresponding stability constants giving the best fits of the $\mathrm{pH}$ metric titration curves are presented in Table 1.

$\mathrm{UV}-\mathrm{Vis}$ measurements were performed on the binary and ternary systems. A Beckman DU68 spectrophotometer was used to record the electronic absorption spectra in the range of 300-900 $\mathrm{nm}$ at room temperature. The path length was either 1 or $2 \mathrm{~cm}$. The measurements were carried out in aqueous solutions, at different $\mathrm{pH}$ values $(0.3 \mathrm{pH}$ unit step) between 2.5 and 11 , and at all metal-to-ligand ratios studied, with $4 \times 10^{-3} \mathrm{~mol} \cdot \mathrm{dm}^{-3}$ copper(II) ion concentration. All of the solutions were freshly prepared using bi-distilled water. The metal ion-to-ligand ratios for the copper(II): $\beta$-Ala $(\mathrm{P})$ binary system are $1: 1$ and

Table 1 Cumulative formation constants $\left(\log _{10} \beta\right)$, derived equilibrium constants $\left(\log _{10} K\right)$, and characteristic parameters for the stability of complexes formed in the ternary systems $\mathrm{Cu}^{2+}$-amine (en, dien or $\mathrm{Me}_{5}$ dien)- $\beta$-alaninephosphonic acid $(\beta-\mathrm{Ala}(\mathrm{P}))$ at $25.00{ }^{\circ} \mathrm{C}$ and $I=0.2 \mathrm{~mol} \cdot \mathrm{dm}^{-3}(\mathrm{KCl})$

\begin{tabular}{|c|c|c|c|c|}
\hline \multirow[t]{2}{*}{$\mathrm{Nr}$} & \multirow[t]{2}{*}{ Assignments } & \multicolumn{3}{|c|}{ System $\mathrm{Cu}^{2+}-\mathrm{L}_{1}-\beta-\mathrm{Ala}(\mathrm{P}) ;\left(\mathrm{L}_{1}=\mathrm{en}\right.$, dien or $\mathrm{Me}_{5}$ dien $)$} \\
\hline & & $\begin{array}{l}\mathrm{Cu}^{2+}-\mathrm{en}- \\
\beta-\mathrm{Ala}(\mathrm{P})\end{array}$ & $\begin{array}{l}\mathrm{Cu}^{2+} \text {-dien- } \\
\beta-\mathrm{Ala}(\mathrm{P})\end{array}$ & $\begin{array}{l}\mathrm{Cu}^{2+}-\mathrm{Me}_{5} \text { dien- } \\
\beta-\mathrm{Ala}(\mathrm{P})\end{array}$ \\
\hline 1. & $\log _{10} \beta\left[\mathrm{Cu}\left(\mathrm{L}_{1}\right)(\beta-\mathrm{Ala}(\mathrm{P}))\right]$ & $17.37(1)$ & $19.85(3)$ & $16.59(1)$ \\
\hline 2. & $\log _{10} \beta\left[\mathrm{Cu}\left(\mathrm{L}_{1}\right)(\beta-\mathrm{Ala}(\mathrm{P})) \mathrm{H}_{-1}\right]^{-}$ & $6.17(2)$ & - & - \\
\hline 3. & $\log _{10} K_{\left[\mathrm{Cu}\left(\mathrm{L}_{1}\right)(\beta-\mathrm{Ala}(\mathrm{P}))\right]^{\mathrm{a}}}$ & 6.79 & 3.84 & 4.12 \\
\hline 4. & $\log _{10} K_{\left[\mathrm{Cu}\left(\mathrm{L}_{1}\right)\left(\mathrm{L}_{2}\right)\right]}-\mathrm{p} K_{\mathrm{NH}_{3}^{+}}-\mathrm{p} K_{\mathrm{PO}_{3} \mathrm{H}^{-}}$ & -10.29 & -13.24 & -12.96 \\
\hline 5. & $\chi^{2}$ & 9.60 & 11.83 & 10.88 \\
\hline 6. & $\sigma$ & 5.91 & 6.98 & 9.98 \\
\hline 7. & $\Delta \log _{10} K^{\mathrm{b}}$ & -1.47 & -4.42 & -4.14 \\
\hline 8. & $\log _{10} X^{\mathrm{c}}$ & 0.47 & 5.43 & - \\
\hline
\end{tabular}

${ }^{a} \log _{10} \quad K_{\left[\mathrm{Cu}\left(\mathrm{L}_{1}\right)(\beta-\mathrm{Ala}(\mathrm{P}))\right]}=\log _{10} \quad \beta_{\left[\mathrm{Cu}\left(\mathrm{L}_{1}\right)(\beta-\mathrm{Ala}(\mathrm{P}))\right]}-\log _{10} \quad \beta_{\left[\mathrm{Cu}\left(\mathrm{L}_{1}\right)\right]} ; \quad \log _{10} \quad \beta_{[\mathrm{Cu}(\mathrm{en})]}=10.58, \quad \log _{10}$ $\beta_{\left[\mathrm{Cu}(\mathrm{en})_{2}\right]}=19.73[19], \log _{10} \beta_{[\mathrm{Cu}(\mathrm{dien})]}=16.01, \log _{10} \beta_{\left[\mathrm{Cu}(\mathrm{dien})_{2}\right]}=20.76[8], \log _{10} \beta_{\left[\mathrm{Cu}\left(\mathrm{Me}_{5} \text { dien }\right)\right]}=12.47$ [9]; $\log _{10} \beta_{[\mathrm{Cu}(\beta-\mathrm{Ala}(\mathrm{P}))]}=8.26, \log _{10} \beta_{\left[\mathrm{Cu}(\beta-\mathrm{Ala}(\mathrm{P}))_{2}\right]}=14.54, \mathrm{p} K_{\mathrm{PO}_{3} \mathrm{H}^{-}}=6.20$ and $\mathrm{p}_{\mathrm{NH}_{3}^{+}}=10.88$ of $\beta-$ $\mathrm{Ala}(\mathrm{P})$ in this work

b $\Delta \log _{10} K=\log _{10} \beta_{\left[\mathrm{Cu}\left(\mathrm{L}_{1}\right)(\beta-\mathrm{Ala}(\mathrm{P})]\right.}-\left(\log _{10} \beta_{\left[\mathrm{Cu}\left(\mathrm{L}_{1}\right)\right]}+\log _{10} \beta_{[\mathrm{Cu}(\beta-\mathrm{Ala}(\mathrm{P})]}\right)$, the constant due to the equilibrium: $\left[\mathrm{Cu}\left(\mathrm{L}_{1}\right)\right]+[\mathrm{Cu}(\beta-\mathrm{Ala}(\mathrm{P}))] \leftrightarrows\left[\mathrm{Cu}\left(\mathrm{L}_{1}\right)(\beta-\mathrm{Ala}(\mathrm{P}))\right]+\mathrm{Cu}$

${ }^{c} \log _{10} X=2 \log _{10} \beta_{\left[\mathrm{Cu}\left(\mathrm{L}_{1}\right)(\beta-\mathrm{Ala}(\mathrm{P})]\right.}-\left(\log _{10} \beta_{\left[\mathrm{Cu}\left(\mathrm{L}_{1}\right)_{2}\right]}+\log _{10} \beta_{\left[\mathrm{Cu}\left(\beta-\mathrm{Ala}(\mathrm{P})_{2}\right]\right.}\right)$, the constant due to the equilibrium: $\left[\mathrm{Cu}\left(\mathrm{L}_{1}\right)_{2}\right]+\left[\mathrm{Cu}(\beta-\mathrm{Ala}(\mathrm{P}))_{2}\right] \leftrightarrows 2\left[\mathrm{Cu}\left(\mathrm{L}_{1}\right)(\beta-\mathrm{Ala}(\mathrm{P}))\right]$; for the $\left[\mathrm{Cu}\left(\mathrm{Me}_{5} \operatorname{dien}\right)(\beta-\mathrm{Ala}(\mathrm{P})]\right.$ heteroligand species the value of this parameter cannot be calculated, since the complex with a 1:2 metal-to-ligand ratio is not formed in the $\mathrm{Cu}^{2+}-\mathrm{Me}_{5}$ dien binary system [9] 
1:2. For the ternary systems copper(II):en: $\beta$-Ala(P), copper(II):dien: $\beta$-Ala(P) and copper(II): $\mathrm{Me}_{5}$ dien: $\beta$-Ala(P), the concentration ratios are 1:1:1 and 1:1:2. These concentration ratios of the reagents were chosen in order to achieve as high as possible concentration of the heteroligand species and to get the lowest concentrations of co-existing species in the solutions. The net ligand-field absorption band of each heteroligand species was extracted from the absorption spectra by applying the procedure described in Ref. [7].

EPR spectra were performed on a Bruker $300 \mathrm{E}$ X-band spectrometer equipped with a Bruker NMR gauss meter ER $035 \mathrm{M}$ and a Hewlett-Packard frequency counter HP 5350B at $-196{ }^{\circ} \mathrm{C}$ and at room temperature. Due to the strong absorption of microwave energy by water, very narrow sample tubes were used for liquid solution measurements. Samples for EPR studies were prepared in water/ethylene glycol (4:1 v/v) solutions to ensure good glass formation with a copper(II) concentration of $4 \times 10^{-3} \mathrm{~mol} \cdot \mathrm{dm}^{-3}$ in all samples. The copper ion-to-ligands molar ratios are the same as those used in the electronic absorption spectra measurements. The binary and ternary systems solutions were usually studied over the same $\mathrm{pH}$ range as in the potentiometric studies. The $\mathrm{pH}$ of solutions was measured using a Mettler-Toledo, MP $2300 \mathrm{pH}$-meter with a combined $\mathrm{pH}$ electrode (SINGLE PORE GLASS, Hamilton). The EPR parameters were calculated by computer simulation of the experimental spectra using Bruker's WIN-EPR SimFonia Software Version 1.25.

\section{Results and Discussion}

The dissociation constants for the ligands and the stability constants of the complexes formed in the binary systems were redetermined under the same experimental conditions as those applied for the ternary systems (ionic strength $0.2 \mathrm{~mol} \cdot \mathrm{dm}^{-3}$, set with $\mathrm{KCl}$ solution). The results are in good agreement with previously published data [8-11, 15-23].

The stoichiometries of the complexes and the corresponding stability constants yielding the best fit of the $\mathrm{pH}$-metric titration curves are shown in Table 1. According to these data, heteroligand complexes with $\left[\mathrm{Cu}\left(\mathrm{L}_{1}\right)(\beta-\mathrm{Ala}(\mathrm{P}))\right]$ stoichiometry are formed in all of the studied ternary systems. However, the concentrations of these species in the present systems are distinctly lower than the concentrations of the heteroligand complexes formed in the ternary systems studied by us earlier with the same polyamines and glycinephosphonic acid [3] or with $\alpha$-alaninephosphonic acid [4]. In the $\mathrm{Cu}^{2+}$-en- $\beta$-Ala(P) ternary system the hydroxo heteroligand $\left[\mathrm{Cu}(\mathrm{en})(\beta-\mathrm{Ala}(\mathrm{P})) \mathrm{H}_{-1}\right]^{-}$species also occur in basic solution. From these results, representative concentration distribution curves calculated at 1:1:2 molar ratios, together with the $\lambda_{\max }$ values of the visible spectra as a function of $\mathrm{pH}$ for $\mathrm{Cu}^{2+}$-en$\beta$-Ala $(\mathrm{P}), \mathrm{Cu}^{2+}-\operatorname{dien}-\beta-\mathrm{Ala}(\mathrm{P})$ and $\mathrm{Cu}^{2+}-\mathrm{Me}_{5} \operatorname{dien}-\beta-\mathrm{Ala}(\mathrm{P})$ ternary systems, are presented in Fig. 1.

The equilibrium constant, $K_{\left[\mathrm{Cu}\left(\mathrm{L}_{1}\right)(\beta-\mathrm{Ala}(\mathrm{P}))\right]}$ (Table 1, row 3), is much lower for the heteroligand species involving the tridentate ligands dien and $\mathrm{Me}_{5}$ dien than for the species containing the bidentate ligand en. Analogous results were obtained for ternary systems of the same polyamines and phosphonic acid [3,4] and for different amino acids in copper(II) solutions $[5,6]$.

Similarly, the obtained value of the $\Delta \log _{10} K$ parameter for $[\mathrm{Cu}(\mathrm{en})(\beta-\mathrm{Ala}(\mathrm{P}))]$ (Table 1, row 7), which characterizes the tendency towards formation of heteroligand complexes [24], is typical for a complex with distorted octahedral geometry and two different bidentate ligands in the coordination sphere of the $\mathrm{Cu}^{2+}$ ion $[25,26]$. Values of this parameter close to -1 were obtained for the heteroligand species of tetragonal 

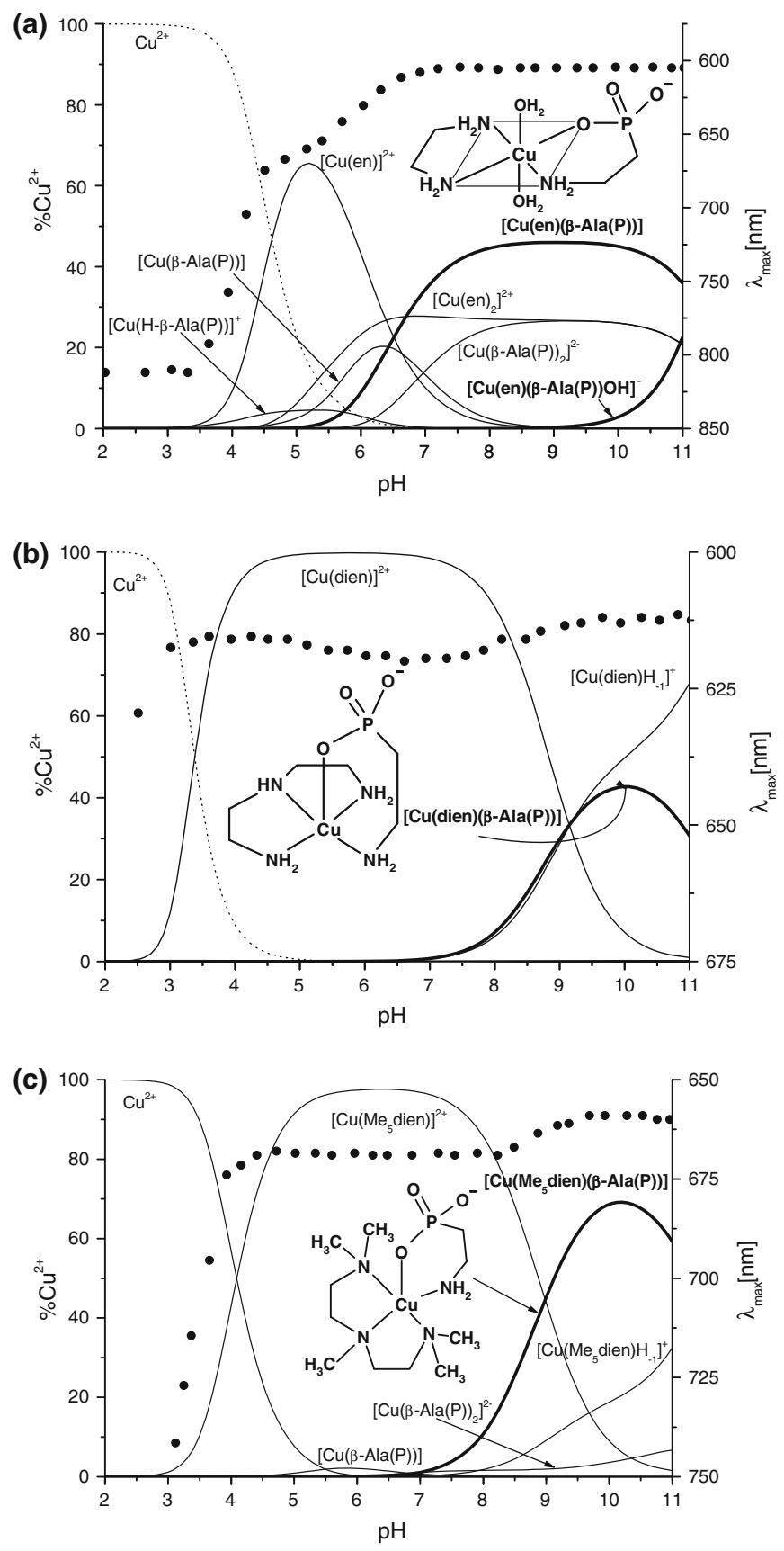

Fig. 1 Species distribution curves as a function of $\mathrm{pH}$ and variations of the visible absorption maximum wavelength (circle) for the $\mathrm{Cu}^{2+}-$ en- $\beta-\mathrm{Ala}(\mathrm{P})$ system $(\mathbf{a}), \mathrm{Cu}^{2+}$-dien- $\beta-\mathrm{Ala}(\mathrm{P})$ system $(\mathbf{b})$, and the $\mathrm{Cu}^{2+}-$ Me $\operatorname{dien}-\beta$-Ala(P) system (c) at 1:1:2 molar ratio where $c_{\mathrm{Cu}^{2+}}=4 \times 10^{-3} \mathrm{~mol} \cdot \mathrm{dm}^{-3}$ 
geometry studied by us earlier, formed by ethylenediamine and other phosphonic acids [3, 4], aminoacids [5, 6], and aminohydroxamic acids in copper(II) solutions [11]. However, in the case of the heteroligand complexes $\left[\mathrm{Cu}\left(\mathrm{L}_{1}\right)(\beta-\mathrm{Ala}(\mathrm{P}))\right]$ with dien or $\mathrm{Me}_{5}$ dien (Table 1 , row 7), the values of $\Delta \log _{10} K$ are clearly lower, most probably because of the lower (than six) coordination number of $\mathrm{Cu}^{2+}$. Such low values of this parameter were found previously in the case of five-coordinate copper(II) heteroligand complexes formed with diethylenetriamine or $N, N, N^{\prime}, N^{\prime}, N^{\prime \prime}$-pentamethyldiethylene triamine with phosphonic acids $[3,4]$, as well as aminoacids or aminohydroxamic acids [5-8, 10, 23].

In turn, the value of the $\log _{10} X$ parameter calculated for the studied heteroligand species (Table 1 row 8$)$ is somewhat lower for $[\mathrm{Cu}(\mathrm{en})(\beta-\mathrm{Ala}(\mathrm{P}))]$ and distinctly higher for $[\mathrm{Cu}(\operatorname{dien})(\beta-\mathrm{Ala}(\mathrm{P}))]$ than are expected on a statistical basis $(0.6)$ [24]. This indicates that, in the studied ternary systems, the formation of heteroligand complexes is favored and it is especially preferred in the system with dien. This is a reflection of the ratio of the stepwise formation constants for the binary $\mathrm{Cu}^{2+}$-amine system $\left(\log _{10}\left(K_{\mathrm{Cu}(\text { dien })} / K_{\mathrm{Cu}(\operatorname{dien})_{2}}\right)=\right.$ 11.26, which is significantly greater than $\log _{10}\left(K_{\mathrm{Cu}(\mathrm{en})} / K_{\mathrm{Cu}(\mathrm{en})_{2}}\right)=1.43$. The same effect was observed for the ternary systems with other studied phosphonic acids and amino acids [3-6].

\section{1 $\mathrm{Cu}^{2+}-$ en- $\beta$-Ala(P) System}

The species distribution curves for the $\mathrm{Cu}^{2+}-\mathrm{en}-\beta-\mathrm{Ala}(\mathrm{P})$ system at 1:1:2 molar ratio as a function of $\mathrm{pH}$, presented in Fig. 1a, indicate that under these experimental conditions $[\mathrm{Cu}(\mathrm{en})(\beta-\mathrm{Ala}(\mathrm{P}))]$ heteroligand species start to form at higher $\mathrm{pH}$ (above $\mathrm{pH} 5.5)$ than the analogous heteroligand species formed in the ternary systems with glycinephosphonic $(\mathrm{Gly}(\mathrm{P}))$ or $\alpha$-alaninephosphonic acids $(\alpha-\mathrm{Ala}(\mathrm{P}))$ [3, 4]. The EPR parameters of the spectra observed up to this $\mathrm{pH}$ in the liquid and frozen solutions $\left(g_{\text {iso }}=2.138\right.$, $A_{\text {iso }}=69 \times 10^{-4} \mathrm{~cm}^{-1}, g_{\|}=2.282, A_{\|}=183 \times 10^{-4} \mathrm{~cm}^{-1}$ ) are almost identical to those stated for the $\mathrm{Cu}^{2+}$-en binary system in an acid solution [11], which confirms that $[\mathrm{Cu}(\mathrm{en})]^{2+}$ predominates. As the $\mathrm{pH}$ of the solution increases, a distinct change of the EPR spectral features can be noticed. At $\mathrm{pH} 6.5$ the spectrum typical of the $[\mathrm{Cu}(\mathrm{en})]^{2+}$ complex is still observed but a spectrum characteristic of $\left[\mathrm{Cu}(\mathrm{en})_{2}\right]^{2+}\left(g_{\text {iso }}=2.101\right.$, $A_{\text {iso }}=84 \times 10^{-4} \mathrm{~cm}^{-1}, g_{\|}=2.203$, and $A_{\|}=196 \times 10^{-4} \mathrm{~cm}^{-1}$ ) is also observed. Just above this $\mathrm{pH}$ a completely new spectrum is observed for coexisting species in equilibrium. It was obtained by subtraction of the EPR signals from the binary species in equilibrium (with suitable contribution), present also in the $\mathrm{Cu}-\mathrm{en}-\beta$-Ala $(\mathrm{P})$ ternary system over the $\mathrm{pH}$ range 8-10. The EPR parameters of this spectrum observed in the liquid and frozen solution at this $\mathrm{pH}$ range $\left(g_{\text {iso }}=2.117, A_{\text {iso }}=77 \times 10^{-4} \mathrm{~cm}^{-1}\right.$ and $g_{\|}=2.237$, $A_{\|}=185 \times 10^{-4} \mathrm{~cm}^{-1}$ ) are completely different from those obtained for the binary systems with $\beta-\mathrm{Ala}(\mathrm{P})$ or en (Tables 2,3$)$. They should be ascribed to the heteroligand species $[\mathrm{Cu}(\mathrm{en})(\beta-\mathrm{Ala}(\mathrm{P}))]$ predicted as being dominant in this $\mathrm{pH}$ range. The values of the EPR parameters are intermediate between those obtained for the bis(ligand) complexes formed by $\beta$-Ala $(\mathrm{P})$ or en (Tables 2,3$)$ and may be unambiguously assigned to the $3 \mathrm{~N}$ donor set, which supports the presence of $[\mathrm{Cu}(\mathrm{en})(\beta-\mathrm{Ala}(\mathrm{P}))]$ heteroligand species (with $\mathrm{NH}_{2}, \mathrm{NH}_{2}, \mathrm{NH}_{2}, \mathrm{PO}_{3}^{2-}$ donor set). Similarly, the energy of $d-d$ transition for the $[\mathrm{Cu}(\mathrm{en})(\beta-$ $\mathrm{Ala}(\mathrm{P}))]$ species, equal to $612 \mathrm{~nm}$, is intermediate between those obtained for the $[\mathrm{Cu}(\beta-$ $\left.\mathrm{Ala}(\mathrm{P}))_{2}\right]^{2-}(642 \mathrm{~nm})$ and $\left[\mathrm{Cu}(\mathrm{en})_{2}\right]^{2+}(549 \mathrm{~nm})$ species with $2 \mathrm{~N}$ and $4 \mathrm{~N}$ coordinations, respectively (Fig. 2a, d; Tables 2, 3). It is easily noticed that the EPR parameters obtained and the absorption spectroscopic data for the studied ternary system are similar to those 


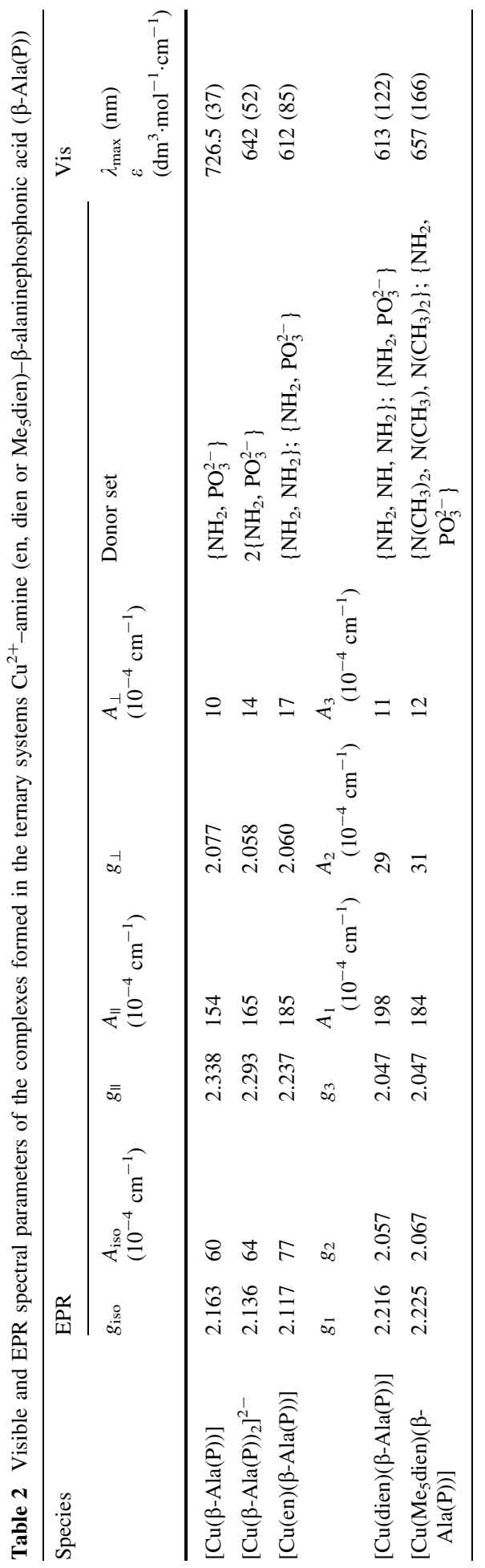




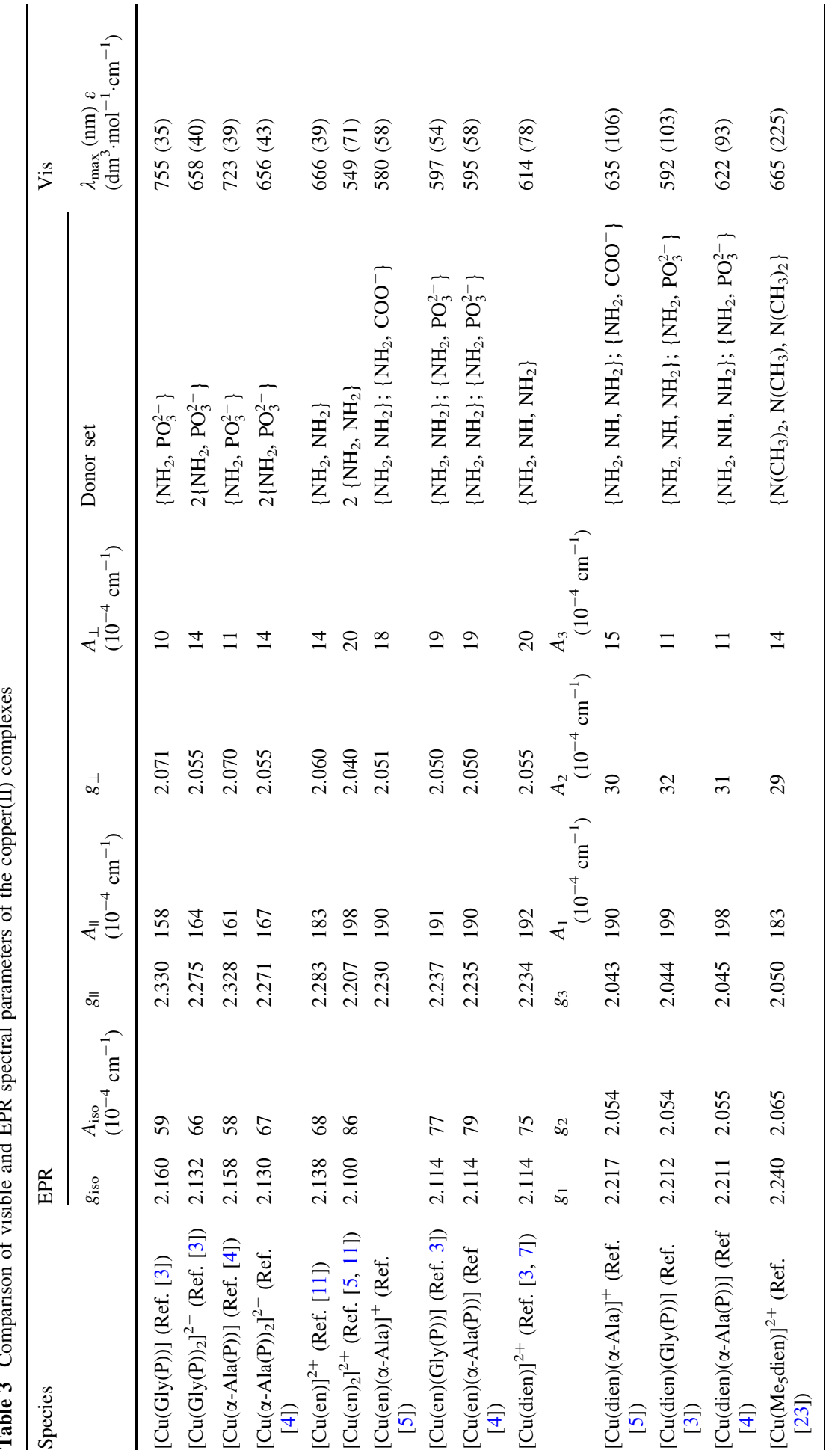




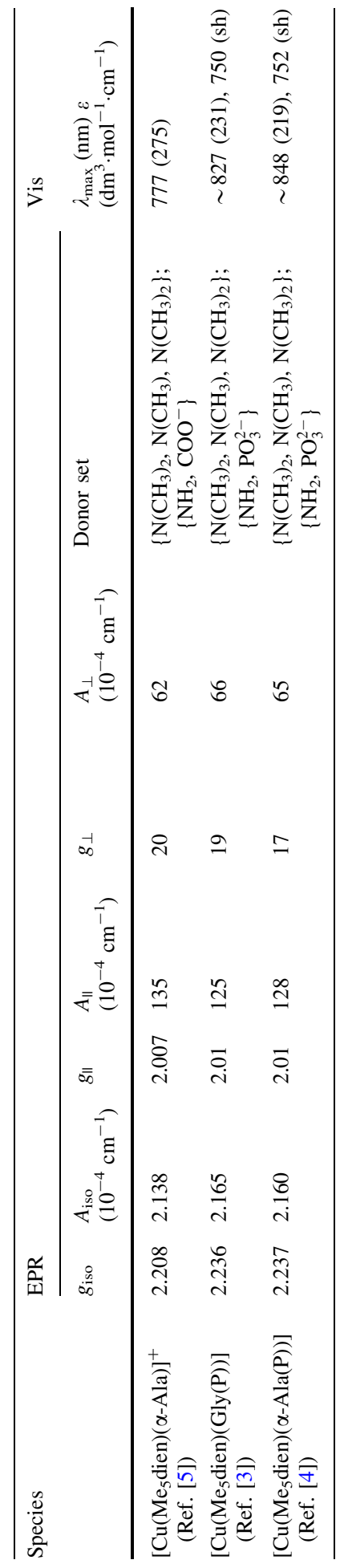



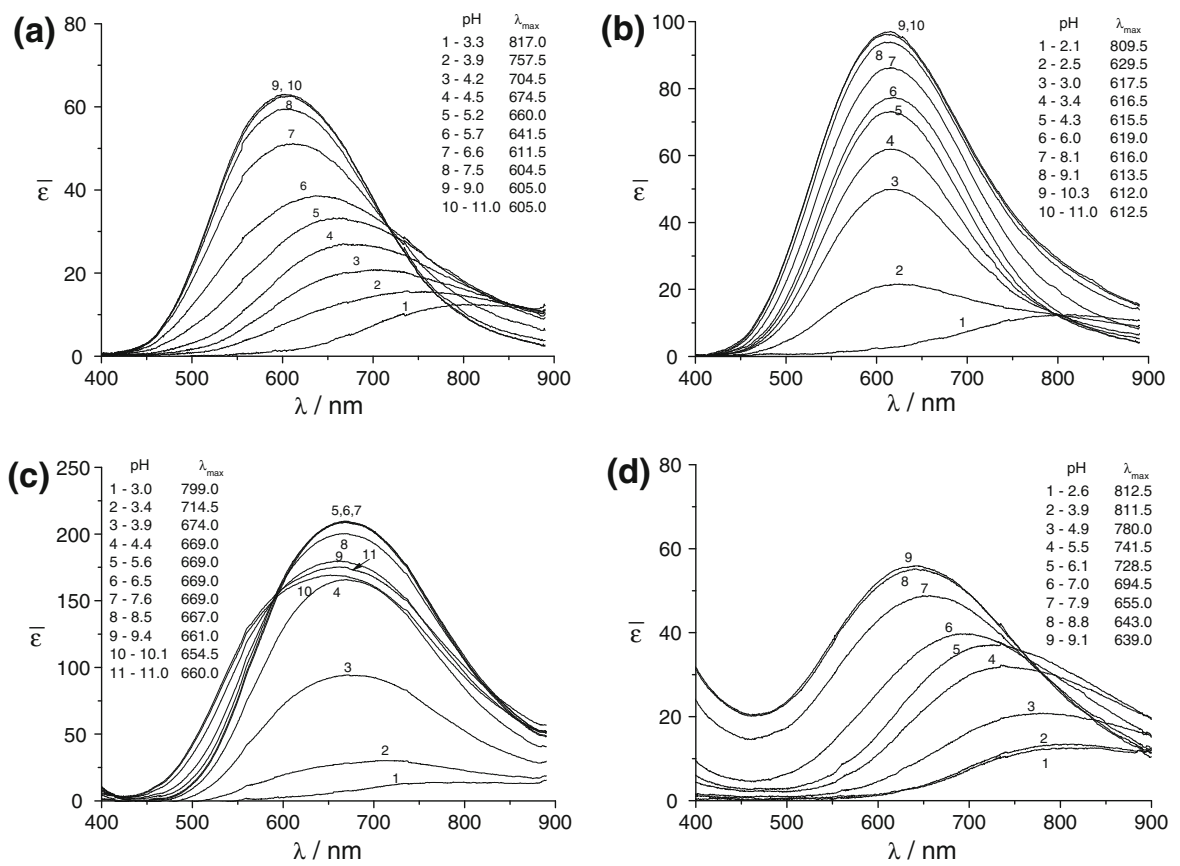

Fig. $2 \mathrm{pH}$-varied absorption spectra of the $\mathrm{Cu}^{2+}-\mathrm{en}-\beta$-Ala $(\mathrm{P})$ system $(\mathbf{a}) ; \mathrm{Cu}^{2+}-$ dien- $\beta$-Ala $(\mathrm{P})$ system $(\mathbf{b})$ at 1:1:2 molar ratio $\left(c_{\mathrm{Cu}^{2+}}=4 \times 10^{-3} \mathrm{~mol} \cdot \mathrm{dm}^{-3}, 2 \mathrm{~cm}\right.$ cells $) ; \mathrm{Cu}^{2+}-\mathrm{Me}_{5} \mathrm{dien}-\beta-\mathrm{Ala}(\mathrm{P})$ system $(\mathbf{c})$ at 1:1:2 molar ratio $\left(c_{\mathrm{Cu}^{2+}}=4 \times 10^{-3} \mathrm{~mol} \cdot \mathrm{dm}^{-3}, 1 \mathrm{~cm}\right.$ cells $)$; and $\mathrm{Cu}^{2+}-\beta$-Ala(P) system at 1:2 molar ratio (d) $\left(c_{\mathrm{Cu}^{2+}}=4 \times 10^{-3} \mathrm{~mol} \cdot \mathrm{dm}^{-3}, 2 \mathrm{~cm}\right.$ cell $)$

corresponding to the heteroligand species formed by en and glycinephosphonic or $\alpha$ alaninephosphonic acid with the same donor atoms in the coordination sphere of copper(II) ions (Table 3) and amino acids [6]. Therefore, they clearly support the formation of $\left(\mathrm{NH}_{2}\right.$, $\left.\mathrm{NH}_{2}\right)$ and $\left(\mathrm{NH}_{2}, \mathrm{PO}_{3}^{2-}\right)$ chelates in the plane of $[\mathrm{Cu}(\mathrm{en})(\beta-\mathrm{Ala}(\mathrm{P}))]$. Above $\mathrm{pH} 10$, a small change in the EPR spectrum may be attributed to a small amount of the next heteroligand species, $\left[\mathrm{Cu}(\mathrm{en})\left(\beta-\mathrm{Ala}(\mathrm{P}) \mathrm{H}_{-1}\right]^{-}\right.$.

\section{$3.2 \mathrm{Cu}^{2+}-$ dien- $\beta$-Ala(P) System}

As is well demonstrated in Fig. 1b, under the applied experimental conditions $\left\{\mathrm{Cu}^{2+}: \operatorname{dien}: \beta-\mathrm{Ala}(\mathrm{P})\right.$ at $1: 1: 2$ molar ratio $\}$, the $\beta$-Ala $(\mathrm{P})$ ligand begins to interact with the $[\mathrm{Cu} \text { (dien) }]^{2+}$ species above $\mathrm{pH}$ 7.5. In the $\mathrm{pH}$ range 4-7, the EPR spectrum typical for the $[\mathrm{Cu}(\text { dien })]^{2+}$ complex $\left(g_{\text {iso }}=2.114, A_{\text {iso }}=76 \times 10^{-4} \mathrm{~cm}^{-1}\right.$ and $g_{\|}=2.234, A_{\|}=$ $194 \times 10^{-4} \mathrm{~cm}^{-1}$ ) is observed and is predominant in the liquid and frozen solutions. Upon increasing the solution $\mathrm{pH}$, a distinct change of the EPR spectral feature can be noticed. The spectrum corresponding to the $[\mathrm{Cu}(\text { dien })]^{2+}$ complex is still observed and is dominant between $\mathrm{pH}=7.0$ and 8.5 , but above $\mathrm{pH} 8.0$ a new spectrum is also observed. This new spectrum observed in the frozen solution, with parameters $g_{1}=2.216, g_{2}=2.057$, $g_{3}=2.047$ and $A_{1}=198, A_{2}=29, A_{3}=11 \times 10^{-4} \mathrm{~cm}^{-1}$, that is clearly observed in the $\mathrm{pH}$ range $9.0-10.5$ in this ternary system, is obviously different from those recorded for the 
Fig. 3 Distribution-corrected absorption spectra for the $[\mathrm{Cu}(\mathrm{en})(\beta-\mathrm{Ala}(\mathrm{P}))],[\mathrm{Cu}(\operatorname{dien})(\beta-$ $\mathrm{Ala}(\mathrm{P}))],\left[\mathrm{Cu}\left(\mathrm{Me}_{5} \operatorname{dien}\right)(\beta-\right.$ $\mathrm{Ala}(\mathrm{P}))],\left[\mathrm{Cu}(\beta-\mathrm{Ala}(\mathrm{P}))_{2}\right]^{2-}$, $\left[\mathrm{Cu}(\mathrm{en})_{2}\right]^{2+},[\mathrm{Cu}(\text { dien })]^{2+}$, and $\left[\mathrm{Cu}\left(\mathrm{Me}_{5} \text { dien }\right)\right]^{2+}$ species

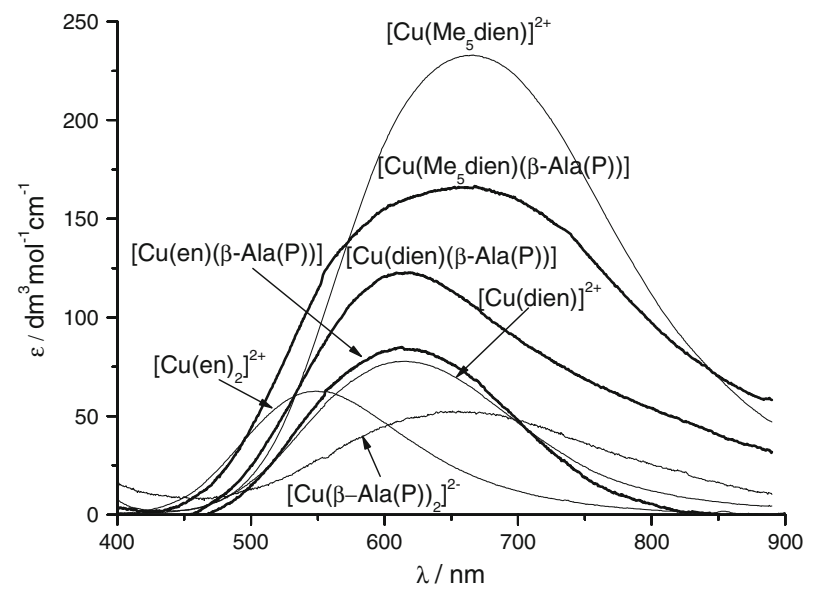

$\mathrm{Cu}^{2+}$-dien or $\mathrm{Cu}^{2+}-\beta-\mathrm{Ala}(\mathrm{P})$ binary systems in this $\mathrm{pH}$ range. These results unambiguously show the existence of the heteroligand species $[\mathrm{Cu}(\operatorname{dien})(\beta-\mathrm{Ala}(\mathrm{P}))]$ in this ternary system. The EPR parameters obtained for this species are consistent with those corresponding to a five-coordinate species formed by dien and other phosphonic acid or amino acids or in the frozen copper(II) solution (Table 3) [3-6]. Therefore, $\beta$-Ala(P), similarly to $\mathrm{Gly}(\mathrm{P})$ or $\alpha-\mathrm{Ala}(\mathrm{P})$, completes the coordination number of five by binding amine nitrogen in the $\mathrm{Cu}^{2+}$ plane and phosphonic oxygen in the axial position. This assumption is supported by characteristics of five-coordinate asymmetry in the isolated electronic absorption spectrum obtained for the $[\mathrm{Cu}(\operatorname{dien})(\beta-\mathrm{Ala}(\mathrm{P}))]$ species over the $\mathrm{pH}$ range $9.5-10.5$ (Fig. 3) [3-6, 8]. Based on the EPR results (the presence of a weak rhombic distortion, Table 2), it can also be concluded that, similar to other heteroligand species of this type, the geometry of the $[\mathrm{Cu}(\operatorname{dien})(\beta-\mathrm{Ala}(\mathrm{P}))]$ complex slightly deviates from square pyramidal towards trigonal bipyramidal [27]. Summing up, the structures of this heteroligand species are presented in Fig. $1 \mathrm{~b}$ and the donor set, $\left\{\mathrm{NH}_{2}, \mathrm{NH}, \mathrm{NH}_{2}\right\}\left\{\mathrm{NH}_{2}, \mathrm{PO}_{3}^{2-}\right\}$, is the same as for other heteroligand species formed by the tridentate ligand dien and studied earlier for bidentate phosphonic acids [3, 4].

\section{$3.3 \mathrm{Cu}^{2+}-\mathrm{Me}_{5}$ dien- $\beta$-Ala(P) System}

Representative concentration distribution curves calculated for the $\mathrm{Cu}^{2+}-\mathrm{Me}_{5} \mathrm{dien}-\beta$ $\mathrm{Ala}(\mathrm{P})$ system at 1:1:2 molar ratio, together with $\lambda_{\max }$ values of the $d-d$ band, are presented in Fig. 1c. As Fig. 1c shows, up to $\mathrm{pH} \sim 7.5$ the simple species with $\mathrm{Me}_{5}$ dien is practically the only one present in the solution under these experimental conditions. Simple species with $\beta$-Ala $(\mathrm{P})$ are formed in very low concentration (less than $5 \%$ ). The EPR parameters of the spectra observed below $\mathrm{pH} 7.5$ in the liquid solution $\left(g_{\text {iso }}=2.119\right.$, $\left.A_{\text {iso }}=74 \times 10^{-4} \mathrm{~cm}^{-1}\right)$ and frozen solution of this ternary system $\left(g_{\mathrm{z}}=2.238\right.$, $g_{\mathrm{x}}=2.067, g_{\mathrm{y}}=2.046$ and $A_{\mathrm{z}}=180, A_{\mathrm{x}}=24, A_{\mathrm{y}}=13 \times 10^{-4} \mathrm{~cm}^{-1}$ ) correspond well to those calculated for $\left[\mathrm{Cu}\left(\mathrm{Me}_{5} \mathrm{dien}\right)\right]^{2+}$ formed in the binary system (Table 3 ). As the $\mathrm{pH}$ of the solution is increased above $\mathrm{pH} 7.5$, heteroligand species start to appear. Both the EPR spectra and absorption spectroscopic data support the existence of the $\left[\mathrm{Cu}\left(\mathrm{Me}_{5^{-}}\right.\right.$ 
Table 4 Comparison of the cumulative formation constants $\left(\log _{10} \beta\right)$ and derived equilibrium constants $\left(\log _{10} K\right)$ of heteroligand complexes formed in the $\mathrm{Cu}^{2+}-\mathrm{L}_{1}$ (en, dien, $\mathrm{Me}_{5}$ dien $)-\mathrm{L}_{2}(\mathrm{~L}=\alpha-\mathrm{Ala}, \beta-\mathrm{Ala}$, $\mathrm{Gly}(\mathrm{P})$ and $\alpha$-Ala $(\mathrm{P}))$ systems at $25.00{ }^{\circ} \mathrm{C}$ and $I=0.2 \mathrm{~mol} \cdot \mathrm{dm}^{-3}(\mathrm{KCl})$ (charges are omitted for simplicity)

\begin{tabular}{|c|c|c|c|c|}
\hline Assignments & $\begin{array}{l}\alpha \text {-Ala } \\
\text { Ref. }[5,30]\end{array}$ & $\begin{array}{l}\beta \text {-Ala } \\
\text { Ref. }[10,33]\end{array}$ & $\begin{array}{l}\text { Gly(P) } \\
\text { Ref. [3] }\end{array}$ & $\begin{array}{l}\alpha-\mathrm{Ala}(\mathrm{P}) \\
\text { Ref. [4] }\end{array}$ \\
\hline $\log _{10} \beta\left[\mathrm{Cu}(\mathrm{en})\left(\mathrm{L}_{2}\right)\right]$ & 17.66 & 16.58 & 17.50 & 17.929 \\
\hline $\begin{array}{l}\log _{10} K\left[\mathrm{Cu}(\mathrm{en})\left(\mathrm{L}_{2}\right)\right] \\
{[\mathrm{Cu}(\mathrm{en})]+\mathrm{L}_{2} \rightleftharpoons\left[\mathrm{Cu}(\mathrm{en})\left(\mathrm{L}_{2}\right)\right]}\end{array}$ & 7.08 & 6.00 & 6.92 & 7.349 \\
\hline $\log _{10} K_{\left[\mathrm{Cu}(\mathrm{en})\left(\mathrm{L}_{2}\right)\right]}-\mathrm{p} K_{\mathrm{NH}_{3}^{+}}-\mathrm{p} K_{\mathrm{COOH}}$ & -4.96 & -7.56 & - & - \\
\hline $\log _{10} K_{\left[\mathrm{Cu}(\mathrm{en})\left(\mathrm{L}_{2}\right)\right]}-\mathrm{p} K_{\mathrm{NH}_{3}^{+}}-\mathrm{p} K_{\mathrm{PO}_{3} \mathrm{H}^{-}}$ & - & - & -8.395 & -8.2385 \\
\hline $\log _{10} \beta\left[\mathrm{Cu}(\operatorname{dien})\left(\mathrm{L}_{2}\right)\right]$ & 20.16 & 19.41 & 20.40 & 20.47 \\
\hline $\begin{array}{l}\log _{10} K\left[\mathrm{Cu}(\text { dien })\left(\mathrm{L}_{2}\right)\right] \\
{[\mathrm{Cu}(\text { dien })]+\mathrm{L}_{2} \rightleftharpoons\left[\mathrm{Cu}(\text { dien })\left(\mathrm{L}_{2}\right)\right]}\end{array}$ & 4.13 & 3.40 & 4.39 & 4.46 \\
\hline $\log _{10} K_{\left[\mathrm{Cu}(\mathrm{en})\left(\mathrm{L}_{2}\right)\right]}-\mathrm{p} K_{\mathrm{NH}_{3}^{+}}-\mathrm{p} K_{\mathrm{COOH}}$ & -7.89 & -10.23 & - & - \\
\hline $\log _{10} K_{\left[\mathrm{Cu}(\mathrm{en})\left(\mathrm{L}_{2}\right)\right]}-\mathrm{p} K_{\mathrm{NH}_{3}^{+}}-\mathrm{p} K_{\mathrm{PO}_{3} \mathrm{H}^{-}}$ & - & - & -10.925 & -11.1275 \\
\hline $\log _{10} \beta\left[\mathrm{Cu}\left(\mathrm{Me}_{5} \operatorname{dien}\right)\left(\mathrm{L}_{2}\right)\right]$ & 17.33 & 15.44 & 16.286 & 16.57 \\
\hline $\begin{array}{l}\log _{10} K\left[\mathrm{Cu}\left(\mathrm{Me}_{5} \operatorname{dien}\right)\left(\mathrm{L}_{2}\right)\right] \\
{\left[\mathrm{Cu}\left(\mathrm{Me}_{5} \operatorname{dien}\right)\right]+\mathrm{L}_{2} \rightleftharpoons\left[\mathrm{Cu}\left(\mathrm{Me}_{5} \operatorname{dien}\right)\left(\mathrm{L}_{2}\right)\right]}\end{array}$ & 5.13 & 3.02 & 3.816 & 4.10 \\
\hline $\log _{10} K_{\left[\mathrm{Cu}\left(\mathrm{Me}_{5} \text { dien }\right)\left(\mathrm{L}_{2}\right)\right]}-\mathrm{p} K_{\mathrm{NH}_{3}^{+}}-\mathrm{p} K_{\mathrm{COOH}}$ & -6.89 & -10.61 & - & - \\
\hline $\log _{10} K_{\left[\mathrm{Cu}\left(\mathrm{Me}_{5} \text { dien }\right)\left(\mathrm{L}_{2}\right)\right]}-\mathrm{p} K_{\mathrm{NH}_{3}^{+}}-\mathrm{p} K_{\mathrm{PO}_{3} \mathrm{H}^{-}}$ & - & - & -11.499 & -11.4875 \\
\hline
\end{tabular}

dien) $(\beta-\mathrm{Ala}(\mathrm{P}))]$ complex (maximum concentration nearly $70 \%$ at $\mathrm{pH} 9.5-10.5)($ Fig. $1 \mathrm{c}$ ). The EPR spectral characteristics of this species are observed between $\mathrm{pH} 9.0$ and 11.0.

By deconvolution of the EPR spectra recorded in this $\mathrm{pH}$ range, the individual spectrum for this complex was calculated. The EPR parameters calculated from the separated EPR spectrum of this heteroligand species in frozen solution, $g_{1}=2.225, g_{2}=2.067$, $g_{3}=2.047$ and $A_{1}=184, A_{2}=31$, and $A_{3}=12 \times 10^{-4} \mathrm{~cm}^{-1}$, are typical for the "rhombic" spectrum of five-coordinate heteroligand species with a geometry intermediate between trigonal bipyramid and square pyramid [28, 29]. However, the values of $g$ parameters and the hyperfine splitting constants $A$ of this heteroligand species are different from these obtained for $\left[\mathrm{Cu}\left(\mathrm{Me}_{5} \operatorname{dien}\right)(\mathrm{Gly}(\mathrm{P}))\right], \quad\left[\mathrm{Cu}\left(\mathrm{Me}_{5}-\mathrm{dien}\right)(\alpha-\mathrm{Ala}(\mathrm{P}))\right]$ (Table 3), and heteroligand species of amino acids $\left[\mathrm{Cu}\left(\mathrm{Me}_{5} \text {-dien }\right)(\alpha-\mathrm{Ala})\right]^{+},\left[\mathrm{Cu}\left(\mathrm{Me}_{5^{-}}\right.\right.$ dien $)(\mathrm{Met})]^{+}[6]$, or $\left[\mathrm{Cu}\left(\mathrm{Me}_{5} \text {-dien }\right)(\mathrm{L}-\text { proline })\right]^{+}$and $\left[\mathrm{Cu}\left(\mathrm{Me}_{5} \text {-dien }\right)(\mathrm{L} \text {-valine })\right]^{+}[30]$.

It is very interesting to compare the values of the $\mathrm{R}\left\{\mathrm{R}=\left(g_{\mathrm{y}}-g_{\mathrm{z}} /\left(\mathrm{g}_{\mathrm{x}}-\mathrm{g}_{\mathrm{y}}\right)\right\}\right.$ parameter calculated for heteroligand complexes formed in the $\mathrm{Cu}^{2+}-\mathrm{L}_{1} \mathrm{~L}_{2}$ ternary systems with $\mathrm{L}_{1}=$ dien or $\mathrm{Me}_{5}$ dien and $\mathrm{L}_{2}=\beta$-Ala $(\mathrm{P})$ or $\alpha-\mathrm{Ala}(\mathrm{P})$. The value of this parameter is a measure of the geometric distortion from square pyramid to trigonal bipyramid and the relative contributions of the $d_{z^{2}}$ and $d_{\mathrm{x}^{2}-\mathrm{y}^{2}}$ orbitals in the ground state [29]. For $[\mathrm{Cu}(-\operatorname{dien})(\alpha-\mathrm{Ala}(\mathrm{P}))]$ and $\left[\mathrm{Cu}\left(\mathrm{Me}_{5}\right.\right.$-dien $\left.)(\alpha-\mathrm{Ala}(\mathrm{P}))\right]$ the values of $\mathrm{R}$ are 0.064 and 1.948 [4], respectively, whereas for $[\mathrm{Cu}(-\operatorname{dien})(\beta-\mathrm{Ala}(\mathrm{P}))]$ and $\left[\mathrm{Cu}\left(\mathrm{Me}_{5}-\mathrm{dien}\right)(\beta-\right.$ $\mathrm{Ala}(\mathrm{P}))$ ] they are 0.063 and 0.120 , respectively. This indicates that the greatest contribution is from the $d_{\mathrm{z}^{2}}$ orbital in the ground state and a structure closer to a trigonal bipyramid is found when $\alpha-\mathrm{Ala}(\mathrm{P})$ and $\mathrm{Me}_{5}$ dien are involved in the heteroligand complex due to a dominant bulky effect of two methyl substituents at each nitrogen atom. It is worthwhile to mention that a very strong rhombic distortion in the geometry was also 
observed for phosphonic derivatives of iminodiacetate or nitrilotriacetate complexes, when substitution of the $\mathrm{COO}^{-}$functions by $\mathrm{PO}_{3}^{-2}$ occurs $[31,32]$. It is noteworthy, that for both heteroligand species with dien, the values of this parameter are very small and almost identical and independent of the $\mathrm{L}_{2}$ ligand involved. This suggests that the structure of these complexes is much closer to square pyramidal. However in the case of $\left[\mathrm{Cu}\left(\mathrm{Me}_{5}\right.\right.$-dien $\left.)(\beta-\mathrm{Ala}(\mathrm{P}))\right]$ the value of $\mathrm{R}$ is significantly lower in comparison with the value of this parameter calculated for $\left[\mathrm{Cu}\left(\mathrm{Me}_{5}-\mathrm{dien}\right)(\alpha-\mathrm{Ala}(\mathrm{P}))\right]$ and twice as high as the value obtained for heteroligand species with dien. As a conclusion, it can be suggested that the geometric distortion for the $\left[\mathrm{Cu}\left(\mathrm{Me}_{5}\right.\right.$-dien $)(\beta-\mathrm{Ala}(\mathrm{P}))$ species is stronger than for the heteroligand species containing dien (Table 2$)$ but clearly weaker than for $\left[\mathrm{Cu}\left(\mathrm{Me}_{5^{-}}\right.\right.$ $\operatorname{dien})(\alpha-\mathrm{Ala}(\mathrm{P})]$.

This difference may be assigned to the dissimilar chelate rings formed by both aminophosphonic acids - $\mathrm{a}$ five-membered chelate ring in the case of $\alpha$-Ala(P) and a sixmembered chelate ring in the case of $\beta-\mathrm{Ala}(\mathrm{P})$. It should be mentioned here that similar spectroscopic and structural relations between $\alpha$ - and $\beta$-derivatives are observed in the case of aminohydroxamic acids $[9,23]$. That the $\left[\mathrm{Cu}\left(\mathrm{Me}_{5}\right.\right.$-dien $\left.)(\beta-\mathrm{Ala}(\mathrm{P}))\right]$ complex is dominant between $\mathrm{pH} 9.5$ and 10.5 is also supported by the electronic absorption spectra. The variable $\mathrm{pH}$ absorption spectra of the $\mathrm{Cu}^{2+}-\mathrm{Me}_{5} \mathrm{dien}-\beta-\mathrm{Ala}(\mathrm{P})$ ternary system obtained in basic solutions (Fig. 2c) are different from those for both the $\mathrm{Cu}^{2+}-\mathrm{Me}_{5}$ dien [19] and $\mathrm{Cu}^{2+}-\beta-\mathrm{Ala}(\mathrm{P})$ binary systems (Fig. 2d). The isolated electronic absorption spectrum at $\mathrm{pH} \sim 10.0$ (Fig. 3) exhibits a broad band in the $600-800 \mathrm{~nm}$ range with characteristics of five-coordinate complex asymmetry. Moreover, the energy of the $d-d$ transition for $\left[\mathrm{Cu}\left(\mathrm{Me}_{5}\right.\right.$-dien $\left.)(\beta-\mathrm{Ala}(\mathrm{P}))\right]$ (Fig. 3; Table 2) is consistent with those for fivecoordinated heteroligand species with a $4 \mathrm{~N}$ donor set $[3,4,6]$. Thus, $\beta$ - $\mathrm{Ala}(\mathrm{P})$ completes the coordination number to five by binding in a bidentate manner $\left(\mathrm{NH}_{2}, \mathrm{PO}_{3}^{-2}\right)$.

\subsubsection{Stability Comparisons Among Different $C u^{2+}-L_{1} L_{2}$ Ternary Systems}

It is very interesting to compare the relative stabilities of the complexes formed in the ternary systems with $\alpha$ - and $\beta$-derivative of phosphonic acid with those of amino acids (Tables 1,4). The data clearly show that the relative stabilities of the heteroligand $\left[\mathrm{Cu}\left(\mathrm{L}_{1}\right)\left(\mathrm{L}_{2}\right)\right]$ species with amino acids $[5,10,30,33]$ are about $2-4$ orders of magnitude higher than those for the phosphonic analogues, even though some particular $\alpha$ - and $\beta$ derivatives of amino acid and phosphonic acids form chelate rings of the same size and involve a similar mixed-bonding mode $(\mathrm{N}, \mathrm{O})$. Accordingly, the relative stability decrease for the heteroligand species of $\beta$-Ala $(\mathrm{P})$, which forms six-membered chelate rings, is smaller than those for $\mathrm{Gly}(\mathrm{P})$ or $\alpha$-Ala $(\mathrm{P})$, which form five-membered chelate rings (Tables 1,4 ). This can be explained in part by the significantly larger size of the $\mathrm{PO}_{3}^{-2}$ group. The steric hindrance decreases with increasing size of the chelate ring. The same relative stability decrease effect of phosphonate complexes in comparison to carboxylates was also observed in the case of binary systems with different metal ions [18, 31, 32, 34] and still exists in the ternary system with copper(II) ions. Here is another important point about the relative stability of the heteroligand complexes. The values of the relative stability constants show that the heteroligand complexes formed with $\mathrm{Gly}(\mathrm{P})$ or $\alpha-$ $\mathrm{Ala}(\mathrm{P})$ are more stable than those formed with $\beta$-Ala $(\mathrm{P})$ although the basicity of the coordinating donor groups is higher for the latter ligand. Today we know that the formation of six-membered chelate rings generally results in a decrease of thermodynamic stability and distortion of the coordination geometry of the complexes. 


\section{Conclusions}

In the copper(II)-polyamine- $\beta$-Ala $(\mathrm{P})$ ternary systems studied, the potentiometric, VIS and EPR results support the formation of heteroligand complexes with $\left[\mathrm{Cu}\left(\mathrm{L}_{1}\right)(\beta-\mathrm{Ala}(\mathrm{P}))\right]$ stoichiometry. In the case of the $[\mathrm{Cu}(\mathrm{en})(\beta-\mathrm{Ala}(\mathrm{P}))]$ species, which is present in basic solutions, the formation of $\left(\mathrm{NH}_{2}, \mathrm{NH}_{2}\right)$ and $\left(\mathrm{NH}_{2}, \mathrm{PO}_{3}^{-2}\right)$ chelates in the equatorial plane of the copper(II) ion is supported. In contrast, complexes of the other heteroligand species with tridentate amines are five-coordinate. For the $[\mathrm{Cu}(\operatorname{dien})(\beta-\mathrm{Ala}(\mathrm{P}))]$ species, a geometry that deviates slightly from square pyramidal is postulated. In this heteroligand species the binding of $\mathrm{Cu}^{2+}$ in the equatorial plane is realized by the three amine nitrogens of dien, and the amine nitrogen of $\beta-\mathrm{Ala}(\mathrm{P})$ and phosphonic oxygen complete the coordination number of five by binding to $\mathrm{Cu}^{2+}$ in the axial position. The coordination mode in the heteroligand species containing $\mathrm{Me}_{5}$ dien is the same as in the case of dien, but the geometric distortion for the $\left[\mathrm{Cu}\left(\mathrm{Me}_{5}-\mathrm{dien}\right)(\beta-\mathrm{Ala}(\mathrm{P})]\right.$ species is stronger than for the $[\mathrm{Cu}(\operatorname{dien})(\beta-\mathrm{Ala}(\mathrm{P}))]$ species. The arrangement of the donor atoms in $\beta$ - $\mathrm{Ala}(\mathrm{P})$ allows the formation of a six-membered $(\mathrm{N}, \mathrm{O})$ chelate and results in a decrease of thermodynamic stability and the distortion of the coordination geometry of the complexes, in contrast to the heteroligand species with five-membered chelates such as in the case of the $\alpha$-derivatives of aminophosphonic acid.

Acknowledgments I would like to express my deep and sincere gratitude to Prof. Barbara Kurzak for her review, detailed and constructive comments, and excellent advice during the preparation of this manuscript. I also wish to express my thanks to Prof. Julia Jezierska who gave me the important guidance in the EPR studies.

Open Access This article is distributed under the terms of the Creative Commons Attribution License which permits any use, distribution, and reproduction in any medium, provided the original author(s) and the source are credited.

\section{References}

1. Nowack, B.: Environmental chemistry of phosphonates. Water Res. 37, 2533-2546 (2003)

2. Naydenova, E.D., Todorov, P.T., Troev, D.T.: Recent synthesis of aminophosphonic acids as potential biological importance. Amino Acids 38, 23-30 (2010)

3. Kamecka, A., Kurzak, B., Jezierska, J., Woźna, A., Broda, M.: Stabilities and coordination modes of glycinephosphonic acid in copper(II) heteroligand complexes with ethylenediamine, diethylenetriamine or $N, N, N^{\prime}, N^{\prime}, N^{\prime \prime}$-pentamethyldiethylene triamine in aqueous solution. Struct. Chem. 21, 347-355 (2010)

4. Kamecka, A., Kurzak, B., Jezierska, J., Woźna, A.: Stabilities and coordination modes of $\alpha$-alaninephosphonic acid in copper(II) heteroligand complexes with ethylenediamine, diethylenetriamine or $N, N, N^{\prime}, N^{\prime}, N^{\prime \prime}$-pentamethyldiethylene triamine in aqueous solution. J. Solut. Chem. 40, 1041-1054 (2011)

5. Kurzak, B., Kamecka, A., Bogusz, K., Jezierska, J.: Stabilities and coordination modes of histidine in copper(II) mixed-ligand complexes with ethylenediamine, diethylenetriamine or $N, N, N^{\prime}, N^{\prime}, N^{\prime \prime}$-pentamethyldiethylenetriamine in aqueous solution. Polyhedron 27, 2952-2958 (2008)

6. Kurzak, B., Kamecka, A., Bogusz, K., Jezierska, J., Woźna, A.: Stabilities and coordination modes of methionine in copper(II) mixed-ligand complexes with ethylenediamine, diethylenetriamine or $N, N, N^{\prime}, N^{\prime}, N^{\prime \prime}$-pentamethyldiethylenetriamine in aqueous solution. Polyhedron 28, 2403-2410 (2009)

7. Kurzak, B., Kroczewska, D., Jezierska, J.: Ternary copper(II) complexes with diethylenetriamine and $\alpha-$ (or $\beta$-) alaninehydroxamic acids in water solution. Polyhedron 17, 1831-1841 (1998)

8. Kurzak, B., Bogusz, K., Kroczewska, D., Jezierska, J.: Mixed-ligand copper(II) complexes with diethylenetriamine and histidine- or methioninehydroxamic acids in water solution. Polyhedron 20, 2627-2636 (2001) 
9. Kroczewska, D., Bogusz, K., Kurzak, B., Jezierska, J.: Potentiometric and spectroscopic study of mixed-ligand copper(II) complexes with $N, N, N^{\prime}, N^{\prime}, N^{\prime \prime}$-pentamethyldiethylenetriamine and $\alpha$ - (or $\beta$-) alaninehydroxamic acids in water solution. Polyhedron 21, 295-303 (2002)

10. Kurzak, B., Kamecka, A., Bogusz, K., Jezierska, J.: Unexpected formation of the copper(II) dinuclear mixed-ligand species in the ternary system of $N, N, N^{\prime}, N^{\prime}, N^{\prime \prime}$-pentamethyldiethylenetriamine with methionine- or histidinehydroxamic acids in aqueous solution. Polyhedron 26, 4345-4353 (2007)

11. Kurzak, B., Kamecka, A., Bogusz, K., Jezierska, J.: Coordination modes of histidine- or methioninehydroxamic acids in copper(II) mixed-ligand complexes with ethylenediamine in aqueous solution. Polyhedron 26, 4223-4227 (2007)

12. Gran, G.: Determination of the equivalent point in potentiometric titrations. Acta Chem. Scand. 4, 559-577 (1950)

13. Molina, M., Melios, C., Tognolli, J.O., Luchiari, L.C., Jafelicci Jr., M.: A simple and accurate evaluation of hydrogen-ion concentrations in aqueous solutions of fixed ionic strength. J. Electroanal. Chem. 105, 237-246 (1979)

14. Gans, P., Sabatini, A., Vacca, A.: Investigation of equilibria in solution. Determination of equilibrium constants with the HYPERQUAD suite of programs. Talanta 43, 1739-1753 (1996)

15. Wozniak, M., Nowogrocki, G.: Acidites et complexes des acides (alkyl- et aminoalkyl-) phosphoniques-I: determination potentiometrique des constantes d'acidite par affinement multiparametrique: prise en compte de l'impurete carbonate. Talanta 25, 633-641 (1978)

16. Mohan, M., Abbott, E.: Metal complexes of biologically occurring aminophosphonic acids. J. Coord. Chem. 8, 175-182 (1978)

17. Odani, A., Yamauchi, O.: Preferential formation of ternary copper(II) complexes involving substituted ethylenediamines and amino acids with an aromatic side chain. Inorg. Chim. Acta 93, 13-18 (1984)

18. Kiss, T., Balla, J., Nagy, G., Kozłowski, H., Kowalik, J.: Complexes of aminophosphonates. I. Transition metal complexes of aminophosphonic acid analogues of $\alpha$-alanine, $\beta$-alanine, phenylalanine and tyrosine. Inorg. Chim. Acta 138, 25-30 (1987)

19. Kurzak, B., Kroczewska, D.: Potentiometric investigation of ternary complexes of nickel, copper, zinc and cadmium with 1- $\alpha$-alaninehydroxamic acid and ethylenediamine. J. Coord. Chem. 34, 67-76 (1995)

20. Lomozik, L., Bolewski, L., Dworczak, R.: Complex formation in copper(II) ternary systems involving polyamines and diaminocarboxylates studiem by potentiometric and spectroscopic techniques. J. Coord. Chem. 41, 261-274 (1997)

21. Farkas, E., Enyedy, E.A., Micera, G., Garribba, E.: Coordination modes of hydroxamic acids in copper(II), nickel(II) and zinc(II) mixed-ligand complexes in aqueous solution. Polyhedron 19, 1727-1736 (2000)

22. Gąsowska, A., Jastrząb, R., Bregier-Jarzębowska, R., Lomozik, L.: Intermolecular and coordination reactions in the system of copper(II) with adenosine $5^{\prime}$-monophosphate or cytidine $5^{\prime}$-monophosphate and triamines. Polyhedron 20, 2305-2313 (2001)

23. Kroczewska, D., Kurzak, B., Jezierska, J.: The role of the carboxylic group in the copper(II) mixedligand complexes of DL-aspartic acid- $\beta$-hydroxamic acid and polyamines. Polyhedron 25, 678-686 (2006)

24. Sigel, H.: Metal Ions in Biological Systems, vol. 2. Marcel Dekker, Inc., New York (1973)

25. Sigel, H.: Stabilität, Struktur und Reaktivität von ternären $\mathrm{Cu}^{2+}-$ Komplexen. Angew. Chem. 87, 391-400 (1975)

26. Sigel, H.: Ternary $\mathrm{Cu}^{2+}$ complexes: stability, structure, and reactivity. Angew. Chem. Int. Ed. Engl. 14, 394-402 (1975)

27. Azuma, N., Kohno, Y., Izshizu, K., Takakuwa, T., Tsuboyama, S., Tsuboyama, K., Kobayashi, K., Sakurai, T.: Spectroscopic studies on copper(II) complexes of chiral cyclens: $\left[\mathrm{CuN}_{4} \mathrm{Cl}\right]$ chromophores varying from square pyramidal to trigonal bipyramidal stereochemistry. Inorg. Chim. Acta 215, 109-121 (1994)

28. Bencini, A., Bertini, I., Gatteschi, D., Scozzafava, A.: Single-crystal ESR spectra of copper(II) complexes with geometries intermediate between a square pyramid and a trigonal bipyramid. Inorg. Chem. 17, 3194-3197 (1978)

29. Garribba, E., Micera, G.: The determination of the geometry of $\mathrm{Cu}(\mathrm{II})$ complexes: an EPR spectroscopy experiment. J. Chem. Educ. 83, 1229-1232 (2006)

30. Murakami, T., Murata, K., Ishikawa, Y.: Stabilities and spectral properties of five-coordinate mixedligand copper (II) complexes containing $N, N, N^{\prime}, N^{\prime}, N^{\prime \prime}$-pentamethyldiethylenetriamine and $\alpha$-amino acids. Inorg. Chim. Acta 244, 51-56 (1996)

31. Jeżowska-Bojczuk, M., Kiss, T., Kozłowski, H., Decock, P., Barycki, J.: A simple and accurate evaluation of hydrogen-ion concentrations in aqueous solutions of fixed ionic strength. Complexes of 
aminophosphonates. Part 8. Copper(II) complexes of $\mathrm{N}$-(phosphonomethyl)amino acids and related compounds. J. Chem. Soc. Dalton Trans. 6, 811-817 (1994)

32. Buglyo, P., Kiss, T., Dyba, M., Jeżowska-Bojczuk, M., Kozłowski, H., Boushin, A.: Complexes of aminophosphonates-10. Copper(II) complexes of phosphonic derivatives of iminodiacetate and nitrilotriacetate. Polyhedron 16, 3447-3454 (1997)

33. Schischkova, L.: Study of complex-formation of gallium(IIL) with ammonium-sulfate and determination of stability constant of obtained complex by ion-exchange method. Compt. Rend. Acad. Bulg. Sci. 27, 1545-1948 (1974)

34. Kiss, T., Farkas, E., Kozłowski, H., Kowalik, J.: Complexes of aminophosphonates. II. Transition metal complexes of aminophosphonic acid analogues of aspartic acid and glutamic acid. Inorg. Chim. Acta 155, 281-287 (1989) 